\title{
Towards a common trajectory of port labour systems in Europe? The case of the port of Antwerp
}

\author{
Andrea Bottalico \\ University of Milan, Via Conservatorio 7, 20122, Italy
}

\section{A R T I C L E I N F O}

\section{Keywords:}

Port labour systems

Maritime-logistics chain

Port reform

Port of Antwerp

\begin{abstract}
A B S T R A C T
The purpose of this paper is to provide an analysis on the port labour system in Europe. The study aims at investigating the impact of the market players' strategies along the maritime-logistics chain on port labour dynamics, stressing the role of the institutional constraints.

The empirical findings gathered during the fieldwork in the port of Antwerp are presented and discussed. The paper shows how the strategic action of the main players along the maritime-logistics chain is modifying the port labour system analysed. The organizational model of labour in the port selected seems to be undermined by the institutional transition and the cutthroat competition along the entire logistics chain.

The structure of the paper is as follows: After a critical appraisal of the literature review on port labour and the methodological approach used, in the second part the empirical findings are presented. The conclusions provide a summary and a reflection aimed at interpreting the ongoing, common changes of the port labour systems in Europe.
\end{abstract}

\section{Introduction}

Scholars have addressed a variety of topics on port issues over the last decades. The maritime-economic literature shows how dynamics such as consolidation processes, increasing size of vessels, vertical integrations and shipping alliances have transformed the landscape, as well as the market structure (Rodrigues et al., 2015; Alexandrou et al., 2014).

Ports have been strongly influenced by these processes. In particular, scholars have underlined two major forces that affect the port sector: changes in organizational structures as a result of privatization or deregulation, and the efforts of shipping companies to control the whole logistics chain in order to leverage economies of scale (Vanelslander and Sys, 2015).

The strategies of the main players along the maritime-logistics chain have increasingly affected the economic behaviour of the cargo handling companies, posing new challenges for the future of port labour systems and labour relations. On the other hands, gradual changing dynamics occur at the institutional level in the European ports. While the literature produced on the abovementioned processes has been consistent, scholars paid less attention on the extent to which these trends are altering the environment for terminals and port labour systems. Empirical research on port labour systems, on the behaviour of multinational cargo handling companies and the way they handle labour depending on the institutional frameworks within which they operate, is limited. With some exceptions, the existing literature on port labour is dominated by juridical disciplines, whereas the scientific debate on the maritime-port sector, predominantly economic, does not takes labour relations too much into account.

In recent decades, European ports have been integrated into broader supply chains and global production networks (Robinson, 2002). The changes related to the intermodality have been observed by many scholars as resulting from the need to support economic globalisation (Bonacich and Wilson, 2008; Veltz, 2017). Ports have played a key role in this process, alongside the revolution in the logistics chain embodied by the development of the container and of intermodal transport. The variety of labour systems in key European ports is therefore influenced not only by the (institutional and economics) actors involved in the port segment, but also by the global actors operating along the entire logistics transport chain. The competition nowadays is in fact along the whole logistics chain, more and more integrated (Meersman et al., 2009).

Since ports began to develop as nodes within global supply chains and production networks, this paper argues that the labour relations in European ports are currently under a common shifting process (e.g. gradual erosion of regulative assets via the European port policies, impact of market strategies on organizational aspects at workplace, increasing flexibility, etc.). These common changing dynamics that

E-mail addresses: Andrea.bottalico@unimi.it, Andrea.bottalico@unifi.it. 
affect labour relations have to deal with the historical legacies of each port, but what really matter nowadays is the common trajectory that different cases share instead of the superficial differences among them.

The goal of the following paper is therefore to claim this ongoing convergence towards which the European port labour systems are going through the analysis of a single case integrated in global productive networks and embedded in a socio-institutional context. The paper aims at answering the following research questions: Are the labour systems of key European ports diverging or converging at the present time? What are the other key factors shaping these tendencies? Studying the working dynamics in ports can tell us something more general about the relative impact of global productive networks and national institutional constraints on local employment conditions.

The compatibility between national regulations and neoliberal policies at European level has been a strong influence on the variety of port labour systems. The objective of the European institutions in these years has been to liberalise port services, including port labour, according to the principles of the European Treaty on freedom of establishment and freedom to provide services (Article 49 of the TFEU, Treaty on the Functioning of the European Union), whereas national port labour systems in Europe very often tend in the opposite direction. In 2016 a port labour reform took place in Belgium after the infringement procedure sent by the European Union to the Belgian government, concerning the incompatibility of the port labour system with the principles of the Treaty. The same process took place in Spain in 2017 and in Italy before the port reform in 1994. The infringement procedure in Belgium started from the complaints sent to the European Commission by a multinational cargo handling company, involved mainly in logistics activities in the port of Antwerp, and by several interim agencies. After months of talks, the social partners proposed a process of port reform to the European Commission, to be implemented in the coming years. The solution proposed by the Belgian government was positively assessed by the Commission in May 2017 and the infringement procedure was withdrawn. However, what seemed to be the end of a path is actually the beginning of a new phase for the European ports. What will the scenario be when this new phase ends?

The recent economic literature on seaport research and port studies lacks a homogeneous framework for analysing the changing dynamics of port labour systems. These are a delicate topic, with strong contradictions. The final objective of this study, in perspective, is to develop a debate on the factors affecting port competitiveness without overlooking port labour systems and labour relations, by drawing upon the literature review and the empirical results emerged from the paradigmatic case of the port of Antwerp.

\section{Port labour systems and dynamics: A literature review}

Although specific port labour systems apply differently among the European countries, one of the common peculiarities of port labour deals with the uncertain dynamism of the maritime traffic. Dock work depends on the relentless and unpredictable rhythm of the goods.

At the beginning of the twentieth century, most of the goods handled in the European ports were carried out with casual labour over time replaced by recognized dock labour registers, in order to cope with the casual and seasonal nature of this kind of job (Dempster, 2010). The history of port labour is characterized by constantly oscillating processes of casualization and de-casualization.

The management and the governance of port labour are particularly important with regard to the application of the basic rules of the European Treaty, as pointed out by Verhoeven. The organisation of dock labour schemes is mostly subject to Treaty rules on competition at European level (Verhoeven, 2011). The application of these principles to port labour systems is one of the key debates in the port sector. Verhoeven focuses on the compatibility between port labour systems and European policies, showing how delicate is the equilibrium between market requirements and regulations in the port sector. His perspective emphasizes the variety of dock labour schemes in Europe, and the failed process of the European Commission's Directive proposal on port service (Verhoeven, 2011). Strongly contrasted by trade unions (but also from private port terminal operators and public port authorities) the proposal would have introduced the right for service providers in ports to employ personnel of their own choice as well as the right for port users to provide port services with their own personnel. The Commission proposal to "open the market" led to a "war on Europe's waterfront", as pointed out by Turnbull, and was the only Directive to be rejected twice by the European Parliament (Turnbull, 2016).

The debate between Social partners at European level refers to the forms of "protection" of the external pressures to which port labour is subject and the "restrictions" to the free market. Along this line, the study of Verhoeven has the merit of setting the delicate question of labour pool organization, and the complex match between total liberalization and total monopoly of the port services. Nevertheless, there is room for scientific studies that assess empirically the social and economic impacts of such processes.

A study commissioned by the European Commission on port labour provides an overview of the sector by a legal perspective (Van Hooydonk, 2013). The starting point is that the market for various port services is not always "open" to competition. In particular, port labour market is classified as a source of market barriers and restrictive practices and as such a "headwind" against further marketization (Turnbull, 2016). The study maps a comprehensive overview of port labour arrangements in the European ports, assuming the questionable idea that the law ends where the port area begins (Van Hooydonk, 2013).

The reaction of the unions to this study was not long in coming. The ETF (European Transport Workers' Federation), in response has claimed that the study is biased, and that European policy-making accords supremacy to economic freedoms over fundamental social rights (ETF, 2013).

Whereas the contrasting positions are clearly defined among the social partners, it is hard to find objective studies who address the economic and social aspects of these dynamics. By focusing mainly on the industrial relations, Turnbull observes that in the port transport sector, both product and labour market outcomes are the result of a social conflict between the main actors. Some of the existing studies on port labour indeed focus mainly on the social dimension and role of unions (Wilson and Ness, 2017; Fox-Hodess, 2017). Turnbull has observed the changing bargaining power of the dockworkers. Recently, he analysed the marketization processes and neoliberal restructuring in Europe, exploring the evolution of the European port policy. The port transport industry indeed is "one of the remaining transport sectors in Europe where there are still a significant number of market barriers and restrictive practices" (Turnbull, 2016: 2). Turnbull observes that by testing the "legality" of dock labour arrangements against the four freedoms of the single market, the strategy of the Commission has led to a "hollowing out" of the protective institutions of industrial relations in many European ports (Turnbull, 2016).

No impact has been as pervasive as the technological innovation introduced in the organization of port labour, as well as the automation processes, which represent another sensitive issue for the social partners. The idea that automation modifies skills, and that does not overcome them, is not so widespread among the scholars. Automation processes produced unavoidably a contraction of the number of dockworkers. Researchers interested in port innovation usually look at the competitiveness taking for granted the automation trend, without challenging critically the externalities related.

In a recent study, Serra et al. (2016) evaluate alternative scenarios of labour flexibility for dockworkers in maritime container terminals. The authors compare five new scenarios with respect to the current work organization in the Italian container terminals, by increasing the share of daily working flexibility. The result is not surprising: the 
increased flexibility in container terminals operations can led to a significant reduction of the operating costs and greater efficiency. The authors overlook the evidence of an ongoing increased flexibility regardless, dictated by the market strategies of the shipping companies in the pursuit of the economies of scale, and the resulting pressures on the container terminals (e.g. horizontal and vertical integrations, increasing size of vessels, overcapacity, etc.). Another limitation is that the authors consider the specific case of the Italian container terminals, but there is nothing specific in this case. Furthermore, the discussions about the importance of labour flexibility in port areas and the opportunity to implement interventions on flexibility policies cannot disregard the hypotheses that labour flexibility "at all costs" has not been proven to restore port competitiveness. The bias is mainly in the assumption that port competitiveness goes to the abolition of the existing labour regulations.

The issue of port competitiveness has been relevant in the recent years, due mainly to the scenario after the economic crisis in 2008, who produced a decrease of turnover in the main ports, not only in Europe (Aronietis et al., 2010; Meersman and Van de Voorde, 2016; Parola et al., 2016). By evaluating the strengths and weaknesses of ports, a study about port choice from a chain perspective identifies the factors who affect ship operators' port choice criteria in the port of Antwerp, Rotterdam and Hamburg. In addition, the role of the other decision makers, namely freight forwarders and shippers, is stressed. Nazemzadeh and Vanelslander (2015) rank the main influential factors from the port customer's viewpoint. The empirical results show how relevant the following factors are for ship operators, in order of importance: port costs, geographical location, quality of hinterland connection, productivity, and capacity. The analysis confirms that port costs play the most important role in port selection process by all three groups of players.

The ESPO Fact-finding reports analyses the trends in the European port governance (2016). In the study, it emerges that historical and institutional context of reforms matter, and that several factors determine the complexity of port reform processes. The economic objective of reforms, in general, is to improve the competitiveness of ports. However, seaports remain under a public hybrid nature of port authorities' ownership, despite they are moving towards further corporatisation. Nevertheless, port authorities have economic and non-economic objectives, while the main port services are in private hands.

Although the efficiency with which loading and unloading operations in a port takes place remain important cornerstones of port's competitiveness and its ability to generate wider economic effects in terms of employment and value added creation, labour in the field of port studies seems to be a residual item. Studies about ports tend to disregard labour dynamics.

A relevant input for the discussion on the European port labour system comes from the report of Notteboom (2010), prepared for the European Sea Ports Organization (ESPO), an independent lobby for seaport interests at European level. The framework of Notteboom focuses on the market pressures from the main port actors. According to Notteboom, the requirements of the market players identified refer to a maximization of the performance of dockworkers in terms of productivity and flexibility, an optimization of the direct costs of port labour, and a minimization of the indirect costs such as shortages, strikes, incidents, etc. This internal organization takes place within a wider setting of legal and social conditions.

The framework, although meaningful, presents some limitations for a more detailed comprehension of the labour dynamics in the European seaports. In order to provide further insights, four main points have been identified:

1) The perimeter of the framework is well delimited, but the links between the main items of the internal and the external organizations are presented in a deterministic way. In most cases, reciprocity among the items occurs, in particular if we consider port competitiveness. The market-driven approach does not correspond only to the real setting of the port business.

2) The framework allows defining the context, but its broad purpose produces a shallow overview with few empirical evidences in support.

3) The question of the social and institutional conditions, though mentioned, is not sufficiently elaborated, and the justification of the difficulty in the measurement is not satisfactory. The direct impact of the social and institutional contexts on the overall picture needs more attention, whereby the external organization interferes directly and strongly with the internal labour regimes and arrangements.

4) The framework is based on a market driven approach, but needs and actors in this field are not only those of the market. In addition, some economic actors of the market are particularly influent. Consolidation processes, vertical integrations, increasing vessel size, etc., have produced a new scenario, which sharply influence the relationships among the economic actors. It is therefore partially appropriate to put all the chain actors at the same level, since each market player has divergent interests, influencing not only the internal - and the external - organization of port labour, but also the port competitiveness.

The framework provided by Notteboom, although inspiring, alone is not sufficient to explain the changing dynamics of port labour systems related to the complex structure of the maritime-logistics chain. According to Meersman et al. (2009), compared with the past, competition now takes place all along the logistics chains that connect origins to destinations, and involves a multitude of actors, not just shipping companies or ports. However, shipping companies or ports still constitute the central link in the chain. The interest of the maritime economists remains the competitive advantage and the coordination of all activities carried out by both public and private actors, in order to ensure the smooth flow of goods from the ship to the port's hinterland and vice versa. The current configuration of competition is therefore along the whole logistics chain, which is generally formed by three integrated dimensions, as we have already underlined: the maritime activities, the handling of goods in the port area, and the transport services in the hinterland. To understand the new challenges, hence it is necessary to consider their totality.

In the last years, the shipping companies have focused attention on terminal operators and hinterland transport services. Their strategic alliances and ownerships (partly or entirely) of terminal operating companies is a rather widespread phenomenon. In the Northern Range, for example, where the most efficient ports in Europe are located, the main players are global terminal operators and market-leading shipping companies, which cooperate in most cases. Seven main terminal operators are located in twenty terminals, of which one (the subsidiary APM Terminals) is directly owned by a shipping company (Maersk). In thirteen of the twenty terminals there is a form of cooperation with a shipping company (vertical integration or joint ventures), while the other terminals are "independent" (Table 1).

Taking into consideration, for example, the $2 \mathrm{M}$ alliance (Maersk and MSC) it is possible to assess the effort of each of the two partners in the conquest of spaces within the port arena.

- APM Terminals, until 2017, was present in 69 countries with terminals located in 73 ports and 140 hinterland transport services. Being owned by the shipping company A.P. Moller Maersk, APMT is vertically integrated. In addition, Maersk line also offers forwarding and supply chain management services through its Damco company. In this way Maersk Line is present in the entire supply chain.

- Terminal Investment Limited Sàrl (TIL) is the second terminal operating company owned by a shipping company (MSC) and active in Northern Europe. TIL is a terminal operator founded in 2000 to guarantee mooring and capacity for ships of the MSC shipping company. The group manages and operates 36 terminals in 24 countries, most of 
Table 1

cooperation among terminal operators and shipping companies in the northern range (2017). ${ }^{\mathrm{a}}$

\begin{tabular}{|c|c|c|c|}
\hline Terminal operator & Name of terminal & Location & Cooperation with shipping line \\
\hline Eurogate & Container terminal Hamburg & Hamburg & \\
\hline Eurogate & CTB (container terminal Bremerhaven) & Bremerhaven & \\
\hline Eurogate & NTB (North Sea Terminal Bremerhaven) & Bremerhaven & Maersk \\
\hline Eurogate & MSC Gate & Bremerhaven & MSC \\
\hline Eurogate & CTW & Wilhelmshaven & Maersk \\
\hline PSA & Noordzeeterminal & Antwerpen & \\
\hline PSA & Europaterminal & Antwerpen & \\
\hline PSA & MPET & Antwerpen & MSC \\
\hline DP World & Antwerp Gateway & Antwerpen & Cosco pacific, CMA CGM, ZIM \\
\hline DP World & RWG (Rotterdam World Gateway) & Rotterdam & APL, MOL, HMM, CMA CGM \\
\hline DP World (GMP) & Terminal de France & Le Havre & CMA CGM \\
\hline Terminaux de Normandie (TN) & TNMSC & Le Havre & MSC \\
\hline Terminaux de Normandie (TN) & TPO & Le Havre & \\
\hline HHLA & CTA (Container Terminal Altenwerder) & Hamburg & Hapag-Lloyd \\
\hline HHLA & СTB (Container Terminal Burchardkai) & Hamburg & \\
\hline HHLA & CTT (Container Terminal Tollerort) & Hamburg & \\
\hline Hutchinson Ports & ECT Delta terminal Rotterdam & Rotterdam & MSC \\
\hline Hutchinson Ports & ECT Euromax terminal Rotterdam & Rotterdam & Cosco Pacific \\
\hline APM & APM Terminals Rotterdam & Rotterdam & Maersk \\
\hline APM & APM Terminals Maasvlakte II & Rotterdam & Maersk \\
\hline
\end{tabular}

a This table has been elaborated jointly with Anton Esser, researcher from the University of Antwerp (Belgium), department of Transport and Regional Economics

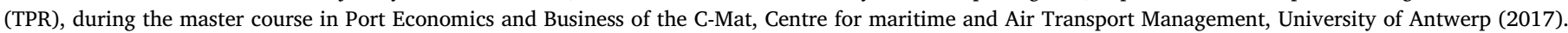

them in joint ventures with other terminal operators.

As the figure below shows (Fig. 1), a multiplicity of elements and drivers overlap each other in the port sector. Regulatory and competitive aspects have to be jointly taken into account, as well as the functional location of a port along the maritime-logistics chain and the spatial location of a port at local, regional and global level. Likewise, the following factors influence port competitiveness:

- Local juridical factors (e.g. national legislations and ongoing reform processes);

- Supranational juridical factors (acquired regulations from the European Union);

- Institutional factors (e.g. port governance, contractual relationships, management structures of dock labour systems, labour regulations)

- Economic factors (market strategies of the global players, competitiveness of services);

- Social factors (working conditions, employment relations, levels and stability of employment and remunerations, conflicts, training, quality of the port labour system).

To sum up, this review of the literature on port labour dynamics allows us to underline two main points: first, the complex and conflictual nature of the port industry. Second, the heterogeneity and the lack of uniform definitions in approaching port labour issues. The analysis of the literature shows a fragmented scenario with endemic issues partially faced by scholars. Port labour is confronted with specific challenges not commonly found in many other industries. Besides the spatial and social definition of port labour, the key issues relate to the definition of dock work, the lacking coherence between supranational and national regulations, ongoing automation processes, etc. The peculiarities of port labour systems and schemes, however, are path dependent and embedded in the history of each port. Finally, it is crucial to develop a debate on the factors that affect port competitiveness without overlooking port labour systems.

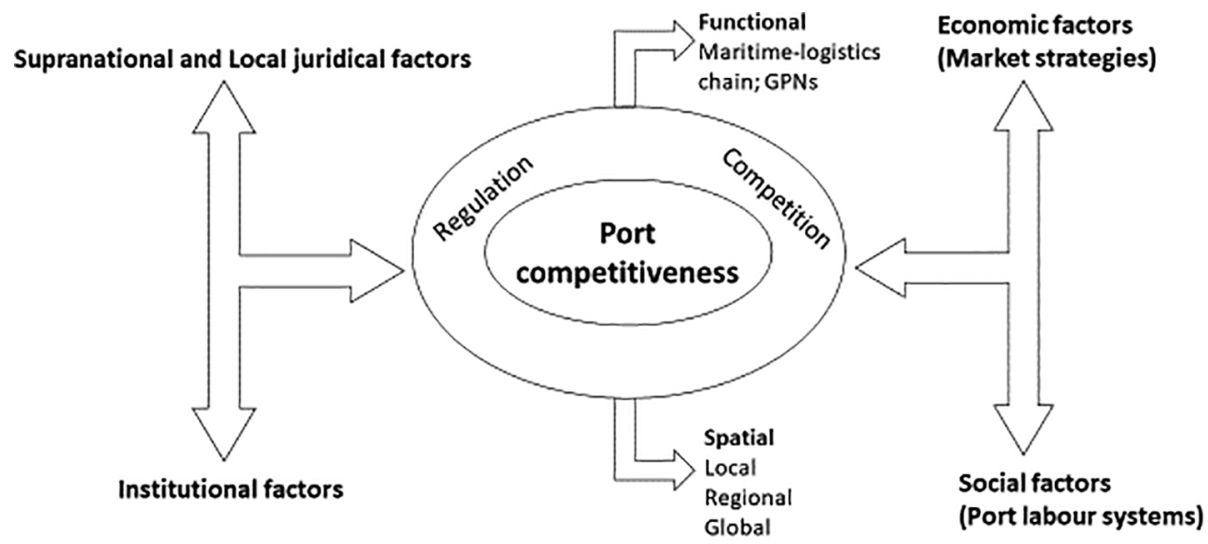

Fig. 1. Factors affecting port competitiveness. 


\section{Methodology}

The case identified is the port of Antwerp (Belgium). The impulse behind this choice refers to the fact that the port labour system is representative, given the significant changing dynamics currently in place.

The methodological itinerary of this research starts from the information gathered during the fieldwork in the port of Antwerp. Drawing upon Yin, five sources of evidence have been considered: Documentation, archival records, interviews, direct observation, and participant observation. Another source consulted and analysed regularly during the fieldwork has been the press review and the specialized newsletters.

The systematic practices of interviews, related to participant observation, have been the most appropriate research techniques. The interviews, open-ended and structured, have been conducted to the key informants. Focused interviews with structured questions have been conducted in addition to corroborate certain facts already established. The direct observation has been necessary in providing additional information about the topic (Yin, 1987). In addition, different sources of information available are used through an "iterative process of puzzling" (Blomme, 2015). Together with the interviews as primary data sources, and the information processed, the systematic collection of secondary data sets the profile of the case.

During the fieldwork, related to the interviews conducted were associated a large number of face-to-face meetings. The participation in conferences and round tables has been an additional driver for the deep understanding of the port environment. The collection of secondary data represents the background for the sharp profile of the Belgian case.

The fieldwork in the port of Antwerp was conducted from October 2016 to May 2017. In this period, twenty-two in-depth and semistructured interviews were conducted to the key actors of the Belgian port and the Northern Range. After the observation stage, a set of interviews were conducted, as primary source of data, to the management of several cargo handling companies, workers, management of labour pool and CEPA (Centrale des Employeurs au Port d'Anvers), board of Voka (Flemish chamber of commerce), unions, etc. Different moments of observations in the hiring hall, in the port area, in the training centre and in some terminals were organized. The visit to the port of Hamburg, Rotterdam and Le Havre has been necessary for a better comprehension of the Northern Range and the features of the port of Antwerp, bearing in mind that, to some extent, a better observation may require distance. A set of interviews has been conducted to the actors involved at European level in the Sectoral Social Dialogue for ports. Two sessions of observations during the works of the Sectoral Social Dialogue have been conducted.

The collection of data retrieved from different and anonymised sources during the fieldwork completes the profile of the Belgian case. It should however be noticed that the limited availability of data, due to their sensitivity, has been the main issue faced during the fieldwork. For this reason, also, the sources of data collected, as well as certain confidential figures, have been both anonymised and elaborated in the respect of the will of the sources themselves. In many cases, the information collected has been processed in data through the elaboration of different sources.

The focus in this study critically engages with the «benchmarking approach» of good or best practices. The search for best practices, indeed, is a misleading issue. It is further acknowledged the importance of the logistics hub of Antwerp in the European port landscape and worldwide. The port of Antwerp, indeed, is among the first European ports in terms of throughput, efficiency, competitiveness, performance, labour productivity, etc. However, this is not a sufficient condition to set a design as a benchmarking aimed at identifying alleged best practices concerning dock labour schemes and work organizations in Antwerp with respect to other European ports. It should be reminded that the acknowledged efficiency and productivity of the Belgian port worldwide did not prevent the European Commission from initiating an infringement procedure concerning the labour organization, in contrast with the principles of the Treaty. This raises many questions for the future of the (best) port labour systems in Europe in relation with the political approach of the European institutions in this field, whose aim is the liberalization of port services, according to the compatibility between port labour systems and principles of the Treaty.

\section{The case of Antwerp: Introduction}

The port of Antwerp is situated in the centre of the Hamburg-Le Havre Range. For those coming from the Mediterranean countries the port of Antwerp can be difficult to frame at first glance, due to its river nature, with docks, locks, barges moored along the canals, and mobile bridges that do not facilitate the orientation. The river bend is sectioned by parcelled spaces, warehouses and storage facilities. The surrounding landscape is flat and spacious. To the north of the river, the borders between Netherlands and Belgium cross the two banks. The North Sea is approximately one hundred kilometres away. The vessels entering the port area are conditioned by the tidal windows of the river and the depth from the estuary to the Western Scheldt.

The economic importance of the Belgian ports for the national economy is highlighted every year in a financial report provided by the National Bank of Belgium (NBB working paper no. 321 - June 2017) ${ }^{1}$. Traditionally, cargo handling in Antwerp was carried out by locally based companies. Gradually, foreign players entered the cargo handling market. Container operators are mainly international firms with their headquarters abroad. The strategic terminals in the port of Antwerp are currently managed by global players and multinational companies and for one terminal in particular through forms of vertical integration between a shipping company and a terminal operating company ${ }^{2}$.

\section{Port governance, port regulation}

In Belgium, ports are currently regulated by the so-called Major Act (8th June 1972), which stipulates that only recognized dockworkers are entitled to do port labour in the port area. The geographical borders set the main difference between the status of dock work inside the port area and the labour conditions of those who handle goods in warehouses outside the port area ${ }^{3}$.

The definition of dock work is on the first page of the so-called "Codex" - the "bible" of the dockworkers -, namely the larger collective bargaining agreement at port level. In each port, the Codex set in detail the prevailing labour regulations applicable within the port. Changes and additions to a Codex are under the responsibility of the Joint Subcommittee made by representatives of both employers and unions (Notteboom, 2010).

The law establishes that all cargo-handling activities within the port area are considered as dock work, therefore in principle the Major Act was not limited to the loading and unloading of ships only ${ }^{4}$. All goods

\footnotetext{
${ }^{1}$ Blomme (2015) explores the value creation in the port of Antwerp.

${ }^{2}$ Although the port of Antwerp is mostly carried out by multinational companies, the infringement procedure sent by the European Commission to the Belgian government concerning the organization of port labour moves from the incompatibility between the national law and the article 49 TFUE, concerning the "freedom of establishment".

${ }^{3}$ The delimitation of the port areas is important, especially for the logistics activities in the warehouses. As the director of VOKA Alfaport observed during the interview, in Ghent all the logistics activities are placed just outside the port area, where the rules of the Belgian port labour schemes are not applicable. This implies the possibility to use a workforce typically non-unionised, migrant, cheaper, and more flexible with respect to the recognized port workers of the Belgian labour pools.

${ }^{4}$ In Belgium, the distinction between intellectual and manual labour takes place. The law that regulates dock labour only talks about manual labour. If the
} 
entering or leaving a Belgian seaport, and all services related to these goods, should be handled by registered port workers (Notteboom, 2010). The exceptions to this general rule refer to the handling of oil products, fishing, etc.

According to the Major Act, the King sets the terms and conditions for the recognition of dockworkers based on the advice of the joint committee for the port area concerned. In general, a candidate has to meet seven conditions to be recognized as a dockworker.

Port companies who employ dockworkers are obliged by the law to join the employers' association, which in the case of the port of Antwerp relates to CEPA (Centrale des Employeurs au port d'Anvers). This employer organization is engaged in the CBA with the unions. Set up in 1929, two main goals are therefore linked to CEPA. First, to structure the labour force to be employed in the port through a list of registered workers entitled to accomplish port labour in the port area (via the mediation of the unions). Second, to set up and organize the system of payment.

The association also has the responsibility for port training of labour force via a training centre, which offers obligatory professional training courses for newly registered dockworkers and special schooling for dockworkers willing to move to another job category.

\section{Organization of the labour pool}

The General Register of the port workers includes port workers of rank A and port workers of rank B who can be subdivided according to their various professional occupations. The new entrants are automatically put in rank B. The transfer from B to A is possible if sufficient shifts have been performed.

According to the nature of labour contract with the port employers, port workers in Antwerp can be further subdivided as permanent and casual workers. They are all recognized dockworkers of the labour pool; the casual workers are hired on a daily basis by means of an unwritten labour contract for a definite period ${ }^{5}$.

The following table shows in detail the number of recognized permanent dockworkers from the pool, employed for ATS on a permanent basis, per each shift and in different container terminals. ATS (Antwerp Terminal Services) is affiliated at CEPA as well. The company (a holding subsidiary of PSA and TIL-MSC) provides dock labour to the main container terminals in the port of Antwerp (Table 2).

Besides the casual workers employed on a daily basis and the semipermanent dockworkers, the dockworkers employed for the main container terminals are working under permanent contracts with ATS (and at the same time, they are members of the labour pool). In total, they are 1483. It is a separate labour contract that grants to these workers of the pool a certain amount of working days. Therefore, in the port of Antwerp, the main container terminal operators prefer to hire permanent workforce, but at the same time, the provision of casual, qualified workforce is in place if needed.

In principle, all the dockworkers belong to the labour pool, with the same conditions. Permanent dockworkers also belong to the pool, but they do not need to go daily to the hiring hall for the hiring sessions, because they have a separate labour contract. When the port employer wants to end their permanent contract, he has to give them notice.

\section{(footnote continued)}

distinction in the port area is very logical, in certain cases this distinction is blurred. Port employers, mainly involved in the conventional cargo, typically use all the loopholes in order to overcome the rigidity of the port law and to avoid the recruitment of recognized dockworkers.

${ }^{5}$ Among this group of casual workers, there are workers hired on a daily basis, by means of an unwritten labour contract, for a definite but long period, but always by the same cargo handling company. Those recognized workers, called in Flemish "binnemannen", "Met contract" or "Vaste arbeiders", have to be considered as quasi-permanent dockworkers. Typically, most of them do not go daily to the hiring hall.
However, as soon as their labour contract is ended, these dockworkers come back into the labour pool through a fall back option - i.e. they can be hired by another port employer, or they can work in a casual way. This is a key aspect of the pool system in the port of Antwerp. Once the permanent contractual relationships with a port employer is ended, these workers always remain part of the pool, but as long as they have a fix contract, they are employees of one port employer. As long as they have a labour contract, they are not allowed to work with other employers in the port. In addition, permanent workers have 52 out of 65 working days guaranteed by the company. Dockworkers for general work can be employed on a permanent basis in container terminals as well. In any case, permanent workers earn the same wages of casual workers of the pool. The main difference is the certainty of the working days. Typically, port workers for general work are however employed in a casual basis. Only for full container terminals, it is possible to work also via contracts on a permanent basis. This detail depends always by the decision of the terminal operator to provide a permanent contract or not. Permanent workers belong typically to specialized categories.

Currently all casual dockworkers must report, in principle, daily at the hiring hall located in the city-centre - called in Dutch het kot - at the time of the engagement session of the shift to which they have been assigned. The hiring hall is owned by the city of Antwerp and functions in collaboration with the Flemish Labour Office, which has the supervision task.

For Monday to Friday, calls are held four times a day. It should be noticed that in 2017 the hiring system started to be partially digitalized. The aim is to engage the casual workers through a hiring system based on a software. In the long run, casual workers could not report themselves anymore to the hiring hall. Many casual workers, in addition, do not need to report daily to the hiring hall. This is the case of the quasipermanent workers, who are engaged daily, in a casual way, by the same employer.

The hiring hall has been described by some workers interviewed as something "like a labour market". In Flemish, dockworkers call the hiring hall "the pigsty" or "cowshed". When entering the hiring hall, currently the casual dockworkers are obliged to record electronically their presence. Dockworkers who have not been engaged are entitled, if they have recorded their presence and if the demand has been met with, to an unemployment indemnity, borne by the National Labour Office.

Besides the strengths of this hiring system, evidenced also by the high performances in the port of Antwerp, one of the main weaknesses often mentioned by the employers refer to their obligation to pick from the pool also workers who they would not pick in other circumstances. In fact, if an employer needs additional workforce, and in the pool few casual workers are available, the employer is obliged to pick among those remained workers. Nevertheless, being the hiring hall the reproduction of a "free market", in principle also the dockworker can choose the port employer he or she prefers.

\section{Composition of the workforce}

Given the same starting point of all the recognized dockworkers and the absence of an incentive system to productivity (not allowed for safety reasons), the question raise about the reason behind the labour productivity. Dockworkers of the port of Antwerp are often cited for having a strong record when it comes to labour productivity (Notteboom, 2010). Nevertheless, why a dockworker in the port of Antwerp should be productive if he or she is not incentivized? In this regard, a foreman suggests that the reason of the productivity has to be found in the "labour culture" of the workers. One important incentive is linked also to the gang system, the job careers, the professional upgrading and the opportunity to be hired in a permanent basis by port employers:

We are all paid the same, there are no incentives. The incentive for me in doing things good and not the other way around is 
Table 2

Port of antwerp. dockworkers employed on a permanent basis.

\begin{tabular}{|c|c|c|c|c|c|c|c|c|c|c|}
\hline \multirow[t]{2}{*}{ Job category } & \multicolumn{3}{|c|}{ Terminal n. 730/1742 } & \multirow[t]{2}{*}{ Total group 730/1742 } & \multicolumn{4}{|c|}{ Terminal n. 869/913/420 } & \multirow[t]{2}{*}{ Total group $869 / 913 / 420$} & \multirow[t]{2}{*}{ TOTAL } \\
\hline & 06:00 & $14: 00$ & $22: 00$ & & 06:00 & 08:00 & $14: 00$ & $22: 00$ & & \\
\hline Assistant chief tallyman & 15 & 14 & 10 & 39 & 10 & 5 & 8 & 7 & 30 & 69 \\
\hline Head foreman & 11 & 11 & 8 & 30 & 6 & 0 & 6 & 4 & 16 & 46 \\
\hline Lasher Head foreman & 2 & 2 & 2 & 6 & 1 & 0 & 1 & 1 & 3 & 9 \\
\hline Driver & 171 & 181 & 97 & 449 & 93 & 1 & 115 & 34 & 243 & 692 \\
\hline Chief tallyman & 4 & 15 & 8 & 27 & 8 & 0 & 9 & 2 & 19 & 46 \\
\hline Foreman & 35 & 36 & 31 & 102 & 16 & 4 & 15 & 12 & 47 & 149 \\
\hline Lasher foreman & 7 & 6 & 6 & 19 & 3 & 4 & 3 & 4 & 14 & 33 \\
\hline General worker & 24 & 18 & 18 & 60 & 9 & 2 & 5 & 5 & 21 & 81 \\
\hline Crane driver & 46 & 47 & 41 & 134 & 23 & 0 & 24 & 12 & 59 & 193 \\
\hline Lasher & 13 & 15 & 11 & 39 & 4 & 0 & 6 & 2 & 12 & 51 \\
\hline Tallyman & 33 & 22 & 18 & 73 & 19 & 1 & 14 & 7 & 41 & 114 \\
\hline Total & 361 & 367 & 250 & 978 & 192 & 17 & 206 & 90 & 505 & 1483 \\
\hline
\end{tabular}

chauvinism. We are proud to be dockers. Simple. You don't want to deliver bad work, no dockers in Antwerp want to produce something bad. Most dockers know that there is a port from here only $100 \mathrm{~km}$, Rotterdam it's on our neck, and they have automated terminals. [Interview with a permanent dockworker, Antwerp, 2017]

A similar answer has been provided by a HR manager of the main container terminal in the port.

With respect to the composition of the workforce, another important aspect concerns the status of the quasi-permanent dockworkers previously mentioned. This "strange connection between casual and permanent labour", emphasized by the president of VOKA Alfaport, underlines the peculiar relationships between status and contract among the Belgian dockworkers. It should however be noted that the relationships between employers and dockworkers is indirect. A critical problem by the viewpoint of the employers refers to the system of sanctioning. An employer can make complaints via the joint subcommittee about the behaviour of the port workers employed, but it is very hard for him to "fire them". Typically, a port employer points on the "emotional account" in order to loyalty a dockworker. The dockworker in Antwerp does not respond directly to the internal hierarchy of the cargo handling company, besides his "hybrid" contractual relationships with the company in Antwerp. The role of (permanent) supervisory staff is crucial in the mediation between the cargo handling company and the dockworkers.

A relevant role in disciplining the workforce is given by the unions. Besides the negotiations for CBA at national and at local level, unions defend the dockworkers in their daily problems, they provide assistance when there are difficulties at the workplace, in the hiring procedures, etc. The majority of the dockworkers are members of one among the three unions.

The bargaining power of the unions is further explained during the interview to the general manager of the main logistics operator in the port involved in conventional cargo. By referring to the possibility to hire workers outside the pool system (parallel system), the interviewee stresses the "contamination risk".

Among the dockworkers of the labour pool in the port of Antwerp, more than 300 are women, employed mostly as tallyman in the container handling process. The total amount of recognized dockworkers belonging to the labour pool is about 6125 .

Inside the port area, therefore, all port employers are compelled to employ recognized port workers of the labour pool to carry out port labour. Only in case of labour pool shortage officially established in the hiring sessions, non-recognized worker may be hired (the so-called pasman, namely workers with only the identity card, without recognition card). The outsourcing of dock labour in the port of Antwerp currently occurs only in case of shortages in the labour pool of recognized workers. Pasmen have generally the same wage conditions of the pool workers. This can only be done when the National Labour
Office in the hiring hall, in a given shift, notices the shortages.

\section{Labour cost and wages}

The table below provides the minimum wage rates related to the job categories, the shifts and the hours. It is clear from the table that the amounts change according to the shifts and the job categories. It should be noted that typically dockworkers in Antwerp are assigned to the same shift for longer periods (Table 3 ).

With respect to the Cash Cost per Box (CCPB), namely the total cost that a container terminal operator pays to handle a container (box), labour composes the main value in the Belgian case. The findings for the ССРВ in the port of Antwerp have been elaborated from different sources, and refer to a container terminal vertically integrated, managed by a global terminal operator. Due to confidentiality, it has been not possible to obtain more details or concrete figures. What it has been possible to know is that the Labour Cost per Container is between 50 and $55 \%$ compared to the Revenue per Container (RPB). About $85 \%$ of CCPB is dock labour related.

The CCPB in Antwerp is approximately $60 €$. Several factors can be underlined to explain this result. First, market reasons: the high competition of the Northern range implies a different strategy of the chain actors, which is however the result of social relations of production. Second, in a container terminal of the port of Antwerp, being the labour cost the fundamental component of the CCPB, the (social) organization at workplace affects heavily the overall value. In theory, few workers are necessary to handle one container in Antwerp from the ship to the shore and vice versa. On the other hand, wages per capita of these workers employed in Antwerp are high. There is enough empirical evidence therefore to state that in the port of Antwerp a low Cash Cost per Box reflects high wages per capita.

In turn, these settings have a positive impact on terminal productivity, as we already emphasized. In the port of Antwerp, the Gross Crane Rate is between 30 and 35 boxes per hour. This is due to several factors (i.e. labour force composition, work organization at quayside, terminal layout, endogenous and exogenous factors, facilities, capacity, volumes handled, gang system, motivation, training, etc.).

With respect to the automation processes, the issue has been addressed during some interviews. The idea among the maritime economists about the automation refers mainly to the new terminals, which will have different technicalities and design. Empirically, this is partially true. The new container terminal transferred from the right to the left bank and built from scratch in the port of Antwerp, has not a different model with respect to the previous terminal. Moreover, during the fieldwork, this brand-new container terminal in the left bank resulted less productive with respect to the previous container terminal in the right bank, due mainly (but not only) to the overcapacity and the congestion of this new terminal. 
Table 3

port of antwerp. minimum wages per category, shifts and hours. Source: Own elaboration from Codex. Gross values. September 2017.

\begin{tabular}{|c|c|c|c|c|c|c|c|c|c|c|c|c|}
\hline \multirow[b]{2}{*}{ Category } & \multicolumn{2}{|c|}{$\begin{array}{l}\text { Dayshift } \\
08: 00-15: 45\end{array}$} & \multicolumn{2}{|c|}{$\begin{array}{l}\text { Morning shift } \\
06: 00-13: 45\end{array}$} & \multicolumn{2}{|c|}{$\begin{array}{l}\text { Afternoon shift } \\
14: 00-21: 45\end{array}$} & \multicolumn{2}{|c|}{$\begin{array}{l}\text { Nightshift } \\
22: 00-05: 45\end{array}$} & \multicolumn{2}{|c|}{ Saturday shifts } & \multicolumn{2}{|c|}{ Sunday-holiday shifts } \\
\hline & Shift/€ & Hour $/ €$ & Shift/€ & Hour $/ €$ & Shift/€ & Hour $/ €$ & Shift/€ & Hour/€ & Shift/€ & Hour/€ & Shift/€ & Hour $/ €$ \\
\hline General worker, Lasher, Tally clerk & 133,37 & 18,40 & 140,40 & 19,32 & 153,38 & 21,16 & 200,06 & 27,59 & 200,06 & 27,59 & 266,74 & 36,79 \\
\hline Foreman, Assistant chief tally clerk & 166,71 & 22,99 & 175,05 & 24,14 & 191,73 & 26,45 & 250,08 & 34,49 & 250,08 & 34,49 & 333,43 & 45,99 \\
\hline Head foreman, Chief tally clerk & 200,06 & 27,59 & 210,06 & 28,97 & 230,07 & 31,73 & 300,09 & 41,39 & 300,09 & 41,39 & 400,11 & 55,19 \\
\hline $\begin{array}{l}\text { Signalman, Forklift driver, Forklift driver with } \\
\text { qualification of crane driver }\end{array}$ & 160,97 & 22,20 & 169,02 & 23,31 & 185,12 & 25,53 & 241,45 & 33,30 & 241,45 & 33,30 & 321,93 & 44,40 \\
\hline $\begin{array}{l}\text { Crane driver, Straddle-carrier driver, Forklift driver } \\
\text { with qualification of crane driver and special } \\
\text { engines }\end{array}$ & 188,57 & 26,01 & 198,00 & 27,31 & 216,86 & 29,91 & 282,84 & 39,01 & 282,84 & 39,01 & 377,12 & 52,02 \\
\hline
\end{tabular}

The sharing idea among the port employers involved in container handling is that in Antwerp a complete automation is in contrast with the path dependent and historical "organization of the improvisation" typically in place at quayside. The "human factor" in the port of Antwerp, so far, is more "flexible" with respect to an automated terminal.

Such overview shows how composite and structured is the port labour system in the Belgian case. These dynamics are routinized throughout the time and legitimated further by the composition of the workforce, in which unions are strongly involved, facing the social role of multinational market players locally situated.

\section{Port labour systems and European port policy: The Belgian reform}

As it has already mentioned, in 2016 a port labour reform took place in Belgium after the infringement procedure sent by the European Union $^{6}$ to the Belgian government, concerning the port labour system. The port law has been changed in order to meet the constraints coming from the European Commission.

Belgium received on $28 / 3 / 2014$ a letter of formal notice ${ }^{7}$ from the European Commission concerning the organisation of port labour, as laid down in the Law of 8 June 1972 and in implementing regulations and collective agreements. The European Commission sent the infringement to Belgium because the port labour system was in contrast to the Article 49 of the Treaty on the Functioning of the European Union (TFEU).

Specifically, five infringements on freedom of establishment were identified by the European Commission (Table 4):

According to the letter of formal notice, the Belgian authorities argued and justified these "restrictions" for two main reasons: First, the general interest to reconcile flexibility and availability of port labour with the protection of the workers intervening in port operations. Second, the need to ensure the quality of the services provided by qualified, skilled port workers, and the need to ensure the safety during port operations (EC, 2014).

The table below shows the timeline of the infringement procedure: (Table 5)

As regards the content of the draft, the Law Major remains unmodified. The main features of the draft agreement are as follows: (Table 6)

To date, the royal decree is changed, but no terminal operators tried to hire a dockworker outside the pool. According to the director of

\footnotetext{
${ }^{6}$ The infringement procedure started from the complaints sent to the European Commission by a multinational cargo handling company based in Belgium, involved mainly in the general cargo and in logistics activities, and by several interim agencies. Container handling companies did not complain the current system.

${ }^{7}$ European Commission. Lettre de mise en demeure - infraction n. 2014/2088
}

Table 4

Infringements identified by the European Commission in the Belgian port labour system (2014)

Prohibition from hiring non-registered workers and the 'obligation' to choose them from the "General Register"

Restriction on the type of contract: indefinite duration is authorised only in exceptional circumstances

Obligation to set a very detailed and extensive gang composition per each shift

Prohibition of multi-tasking or polyvalence

Mandatory registration of logistics port workers

Table 5

Port labour system in Belgium. Timeline of the main events.

11/12/2015: The Belgian Minister for Employment submitted an action plan to the European Commission. The timing of the Plan provided the development of a solution to the letter of formal notice by 1 July 2016

26/04/2016: A preliminary agreement was reached between the social partners

A key element in the pre-agreement has been the adoption by the port workers themselves of a referendum concerning the labour reform (from 31st May 2016 to 14th June 2016)

The draft was presented to the European Commission, with the consequence that no further steps in the procedure were adopted after the letter of formal notice.

The Royal Decree and the collective agreements have been signed and published in the State Gazette. The European Commission took formal note of this and stopped the infringement procedure in May 2017.

Belgium has reached the Belgian action plan to transpose legislation by 1 July 2016 . The reform will then be implemented stepwise, spread over 4 years.

Table 6

Port labour system in Belgium. Features of the agreement.

The recognition of port workers is maintained. The recognition of logistics port workers is withdrawn. A single safety certificate will give them the access to the port area

In the long term, there will be the possibility to hire dockworkers outside the labour pool (parallel circuit), through short and long-term contracts as possible

By way of derogation from the procedure of the gang compositions is accelerated and shall be regularly reviewed

In a number of cases, multi-tasking is also possible, but without making concessions in the fields of safety, and without any negative impact on training and wages

The parallel circuit or system states that recognized workers will also be recruited outside the pool, if the conditions are met. The eighth condition refers to the labour contract for those workers hired outside the labour pool: its duration will correspond to the (temporary) duration of the recognition. A gradual process has been established in order to hire dockworkers outside the pool:

As from 1 July 2016, only port workers with contracts of indefinite duration can be hired;

As from 1 July 2017, only port workers with contracts of at least 2 years; As from 1 July 2018, only port workers with contracts of at least 1 years; As from 1 July 2019, only port workers with contracts of at least 6 months; As from 1 July 2020, port workers for all contracts (e.g. daily contracts) can be hired

CEPA and other port actors, the future scenarios in light of these changes are still uncertain. It should be noticed that the fieldwork in Antwerp has been carried out during this unclear period, whereby the 
reform was in place, but the infringement procedure had not yet been withdrawn. No strikes during this period have been reported.

On 17 May 2017, the Commission has decided to end the infringement procedure. After a long wait, the solution proposed by the Belgian government was positively assessed by the Commission and the infringement procedure was withdrawn.

With regard to the possible scenarios, the choice for the employers to hire personnel in the long run would however not be limited to the labour pool.

Changes will concern also the liberalisation of training. Employers could decide to provide training outside the Training Centre, although they pay a contribution for it. In this case as well, the problem of quality standards occurs.

By the viewpoint of the workers interviewed, the liberalisation processes of the port services, and the infringement procedures related, all derive from the attempt to reduce labour costs in the port. These pressures, according to their perspective, come from the market players of the global maritime supply chain.

\section{Conclusions}

Two main points form the rationale of the following study: First, the variety of port labour systems in the European ports is commonly influenced by not only the economic and social actors in the port segment, but also by the strategies of the global players along the maritime-logistics chain and the institutional actors at supranational and national level.

Second, the main issues related to the variety of port labour systems concern the compatibility between national regulations and port policies at European level. The aim of the European institutions in the last years has been to liberalize port services according to the principles of the Treaty, whereas national port labour systems and schemes in Europe, besides their variety, very often go in the opposite direction. The tables below show a synthesis of the empirical findings (Table 7-9).

The aim of this paper is to develop a discussion on the market requirements linked to job stability in an increasingly uncertain scenario, fair distribution of resources, professional growth of workforce, and the capacity of fairly distributing the economic and employment effects of periodic irregularities of activity / inactivity in cargo handling. This allows an analysis that keeps together the needs of both port operators and workers in the scenarios that will characterize European ports in the future. The wish is at least to tackle these issues by avoiding partial perspectives, typically concerned only about cost reduction and profit maximization via "free-hands approaches" of the market players involved in the port business. Further empirical studies in these directions are needed. There is room for comparative studies among cases, in particular among ports of the Northern Range, and for analysis on the strategies of the market players across the integrated logistics chain.

Are we dealing with a common trajectory of port labour systems in Europe? The empirical findings presented in this study do not allow a sharp answer to this crucial question, due mainly to the fact that we are dealing with an ongoing process. However, the case study analysed suggests that what is taking place is a slow institutional change at national level, coming from the European port policies and previously from the complaints sent by multinational companies to Europe. This is sufficient to argue that the European port labour system may rather converge at a point by the influence of changing market scenarios driven by the strategies of the global economic actors.

The findings photograph this ongoing shift exactly in the middle of the pathway, but additional studies might develop this analysis. Nobody, among the actors interviewed, has been able to foresee the real impact of these trends (market pressures and institutional changes) on port competitiveness. What will the scenario be like when this process is finished? In order to develop a possible answer, a multiplicity of overlapping elements should be considered, as suggested in the Fig. 1. Regulatory and competitive aspects have to be jointly taken into account, as well as the functional location of a port along the maritimelogistics chain and the spatial location of a port at local, regional and global level.

The analysis of port labour systems in Europe requires a multi-scalar investigation, in order to identify how labour dynamics are shaped by these trends. In a competitive scenario, the increasingly concerted efforts of the chain actors to tighten their grip on the maritime-logistics chain (see Table 1) are increasingly affecting port labour systems in terms of increasing flexibility and productivity, unbalanced bargaining power, market pressures, deregulation, etc. Working dynamics in the European ports are therefore commonly influenced by the strategies of a multiplicity of actors across a variety of spatial scales. The institutional transition, as we have seen, seems to boost such dynamics. The behaviour of the main players along the maritime-logistics chain is modifying the working mechanisms of port labour systems, altering the matching of labour supply and demand, opening up new decisionmaking prospects for transnational terminal operating companies. In this frame, labour policies to date have not been carried out, except for de-regulation processes, mainly driven at supranational level and then acquired at national level. In other words, the organizational model of labour in the port selected seems to be undermined by the processes of globalization, cutthroat competition along the entire logistics chain, and Europeization of the port labour policies (Scharpf, 2010).

On the other hands, Dock labour schemes still provide a legal certainty in the national regulations of port labour, despite the existing variety of systems throughout Europe. The legal framework proposed by the European institutions, as we have seen, is far from being oriented towards the creation of a common level playing field. In other words, the supposed common level playing field carried out by the European port policies and regulations concerning port services - and port labour - deals mainly with the liberalisation of the port segment along the (already deregulated) maritime-logistics chain, in line with the neoliberal principles of the European Treaties. Although the European institutions failed so far in the liberalisation of port services by means of Directive, the changing scenario in the maritime supply chain corresponded at the same time to a new approach based on "soft method" by the institutionalization of the conflict in the port industry. In the long run, these market and institutional pressures might produce a slow shift

Table 7

Port labour systems. Key variables.

\begin{tabular}{|c|c|c|}
\hline Variables & Port of Antwerp & Notes \\
\hline Global factors (Container shipping industry) & $\begin{array}{l}\text { Terminal Operating Company Shipping companies, Vertical } \\
\text { integration Strategic alliances; }\end{array}$ & $\begin{array}{l}\text { Exogenous pressures Economies of scale Market and } \\
\text { supply chain requirements }\end{array}$ \\
\hline $\begin{array}{l}\text { Institutional constraints (supranational and } \\
\text { national) }\end{array}$ & Wet Major, 1973 Collective agreement (Codex) & $\begin{array}{l}\text { European port policies, National regulations Labour } \\
\text { contracts }\end{array}$ \\
\hline Port policies and regulations & Labour reform (after infringement procedure) & Current changes in the port sector \\
\hline Port governance and management & Landlord model (Hanseatic tradition) & Public-private partnership \\
\hline Port range & Le Havre - Hamburg range & High competition \\
\hline Port performance measurement & Aggregated & \\
\hline Key Performance Indicators (KPI's) & Container terminals (Limited data availability) & \\
\hline
\end{tabular}


Table 8

Port labour systems. Empirical findings.

\begin{tabular}{|c|c|c|}
\hline Variables & Port of Antwerp & Notes \\
\hline Dock labour scheme & Pool system (under reform) & Hiring system, exogenous pressures \\
\hline Labour pool governance and management & Structured (under reform) & \\
\hline Organization at quayside & Hybrid model, gang system, "emotional account", Slow automation & \\
\hline Professional training & Coordinated (under reform) Professional upgrade & "Beneficial constraint" \\
\hline Employment relations & Collaborative Union bargaining power & Role of the Sectoral Social Dialogue at EU level \\
\hline
\end{tabular}

Table 9

Port performance indicators (Container terminals).

\begin{tabular}{|c|c|c|}
\hline Variables & Port of Antwerp & Notes \\
\hline $\begin{array}{l}\text { Container terminal } \\
\text { productivity(Gross Crane } \\
\text { Rate) }\end{array}$ & $\begin{array}{l}30-35 \text { boxes } \\
\text { (Moves per hour) }\end{array}$ & $\begin{array}{l}\text { KPIs - Average per crane } \\
\text { working hour }\end{array}$ \\
\hline $\begin{array}{l}\text { Cash Cost Per Box (CCPB) } \\
\text { - Wages and Salaries, } \\
\text { - Contract labours, } \\
\text { - Running, Repair, } \\
\text { Maintenance, } \\
\text { - Power and Fuel } \\
\text { - Rental of Equipment and } \\
\text { Facilities, } \\
\text { - Other Direct Charges }\end{array}$ & 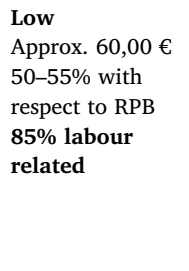 & $\begin{array}{l}\text { Limited data availability } \\
\text { RPB = Revenue Per Box }\end{array}$ \\
\hline $\begin{array}{l}\text { Labour Cost Per Box } \\
\text { Wages }\end{array}$ & $\begin{array}{l}\text { Low } \\
\text { High }\end{array}$ & Limited data availability \\
\hline
\end{tabular}

from the variety of port labour systems throughout Europe towards a common, deregulated landscape. This slow process in turn will probably result in a more uncertain landscape than the existing "incoherent patchwork of jurisprudence and legislation" supposed in the literature (Verhoeven, 2015). The legal certainty at European level does not mean, indeed, a fair and common regulation of the practices adopted at national level concerning dock labour systems, schemes and port services. On the contrary, in line with the changing market scenarios driven by the strategies of the economic actors (in particular the "undisciplined" shipping companies), the port sector might converge towards "different commonalities".

The integration of the key European ports within the global production networks is producing a convergent process of the labour systems at the present time, although we are in the mid of the path. Moreover, institutional variables at supranational and national level, alongside with the economic requirements of the global market players, are shaping these tendencies. In other words, the port industry is «one of the remaining transport sectors in Europe where there are still a significant number of market barriers and restrictive practices» (Thomas, Turnbull, 2016, p. 2), but this might be not necessarily the case in the future. Summing up, in this paper we have seen that the literature on seaport research and port studies lacks a homogeneous framework for analysing the changing dynamics of port labour systems. Additional studies might verify other commonalities, both among ports and across the maritime-logistics chain. In fact, the empirical findings show how ports today are completely integrated within supply chains and global production networks. The economic behaviour of the shipping companies, for instance, explain to what extent the variety of port labour systems is influenced not only by the economic and institutional actors involved in ports - e.g. global terminal operators, port authorities -, but above all by global economic actors operating throughout the logistics chain, that continuously push for deregulating the only segment of the logistics chain that still resists to liberalization processes. By this perspective, European ports might be still shaped by their own different past, but they might be constrained towards a similar future.

\section{Declaration of Competing Interest}

The author declares that he has no known competing financial interests or personal relationships that could have appeared to influence the work reported in this paper.

\section{Acknowledgments}

The author thanks Paolo Perulli, Sergio Bologna, Claudio Ferrari, Anton Esser and the Department of Transport and Regional Economics (TPR), University of Antwerp, Belgium.

This research did not receive any specific grant from funding agencies in the public, commercial, or not-for-profit sectors.

\section{References}

Alexandrou, G., Gounopoulos, D., Hardy, T., 2014. Mergers and Acquisitions in Maritime Industry. Transp. Res. Part E 61, 212-234. https://doi.org/10.1016/j.tre.2013.11. 007.

Aronietis, R., Van de Voorde, E., Vanelslander T. (2010) Port Competitiveness Determinants of Selected European Ports in the Containerized Cargo Market. Paper presented at IAME, International Association of Maritime Economists.

Blomme, J., 2015. Value creation in the port of Antwerp: an investigation of sector and cargo-related creation of value and employment. In: Vanelslander, T., Sys, C. (Eds.), Port business. Market challenges and management actions. UPA, University Press Antwerp, pp. 99-118.

Bonacich, E., Wilson, J.B., 2008. Getting the Goods. Port, Labour, and Logistics Revolution. Cornell University press, Ithaca, NY.

Dempster, J., 2010. The Rise and Fall of the Dock Labour Scheme. Biteback Publishing Ltd, London.

ESPO (2016) "Trends in European ports governance", retrieved 08/06/17 from https:// www.espo.be/media/Trends_in_EU_ports_governance_2016_FINAL_VERSION.pdf.

European Commission (2014) Lettre de mise en demeure - infraction n. 2014/2088, C(2014) 1874 final, Brussels, 28th March 2014.

ETF (2013) The ETF's Response to the study by PORTIUS commissioned by the European Commission (Contract No. MOVE/C2/2010-81/SI2.588013): Port Labour in the EU, Brussels: European Transport Workers' Federation, accessed 26th August 2017 from http://www.etf-europe.org/files/extranet/-75/40738/ETF\%20response\%20to $\% 20$ Portius $\% 20$ study.pdf.

Fox-Hodess, K., 2017. (Re-)Locating the Local and National in the Global: Multi-Scalar Political Alignment in Transnational European Dockworker Union Campaigns. Br. J. Ind. Relations 55, 626-647. https://doi.org/10.1111/bjir.12222.

Meersman, H., Van De Voorde, E., Vanelslander, T., 2009. Scenarios and strategies for the port and shipping sector. In: Meersman, H., Van De Voorde, E. (Eds.), Future challenges for the port and shipping sector. Informa, London, pp. 143-160.

Meersman, H., Van de Voorde, E., 2016. Port competitiveness now and in the future: What are the issues and challenges? Res. Transp. Bus. Manage. 19, 1-3.

National Bank of Belgium (2017) Economic importance of the Belgian ports: Flemish maritime ports, Liège port complex and the port of Brussels - Report 2015, NBB Working paper document N. 321, Brussels.

Nazemzadeh, M., Vanelslander, T., 2015. The container transport system: selection criteria and business attractiveness for north-european ports. Marit. Econ. Logist. 17 (2), 221-245.

Notteboom, T., 2010. Dock Labour and Port-Related Employment in the European Seaport System: Key Factors to Port Competitiveness and Reform, Study Commissioned by the European Sea Ports Organisation (ESPO). University of Antwerp, Antwerp, ITMMA.

Parola, F., Risitano, M., Ferretti, M., Panetti, E., 2016. The drivers of port competitiveness: a critical review. Transport Rev. 1-23.

Robinson, R., 2002. Ports as elements in value-driven chain systems: the new paradigm. Marit. Policy Manage. 29 (3), 241-255.

Rodrigues, A., Ferrari, C., Parola, F., Tei, A., (2015) Competition issues in liner shipping. Note by the secretariat. OECD, DAF/COMP/WP2(2015)3.

Scharpf, F.W., 2010. The asymmetry of European integration, or why the EU cannot be a "social market economy". Socio-Econ. Rev. 8 (2), 211-250.

Serra, P., Fadda, P., Fancello, G., 2016. Evaluation of alternative scenarios of labour flexibility for dockworkers in maritime container terminals. Marit. Policy Manage. 43 (3), 371-385. https://doi.org/10.1080/03088839.2015.1043752. 
Turnbull, P. (2016) Sailing into a storm? Marketization and Industrial Relations in European Ports, Workshop, Cornell University, School of Industrial \& Labour Relations, Marketization and Neoliberal restructuring in Europe, 16th June 2016.

Vanelslander, T., Sys, C. (Eds.), 2015. Port Business, market challenges and management actions. University Press Antwerp, Antwerp.

Van hooydonk, E. (2013) Legal study 2013 - Portius, port labour regimes in the EU Member States: fact-finding exercise, study commissioned by the European Commission, Brussels, final report, 8th January 2013.

Veltz, P. (2017) La société hyper-industrielle: Le nouveau capitalisme productif, Paris,
Seuil.

Verhoeven, P. (2011) Dock labour schemes in the context of EU law and policy, European Research Studies, 14: 2, pp. 149-166.

Verhoeven, P., 2015. Economic assessment of management reform in European seaports. $\mathrm{PhD}$ dissertation. University of Antwerp, Belgium.

Wilson, A.J., Ness, E. (Eds.), (2017) Choke Points. Logistics Workers Disrupting the Global Supply Chain. Pluto Press, London.

Yin, R.K. (1987). Case study research. Design and methods. Applied social research methods series volume 5, SAGE, London. 